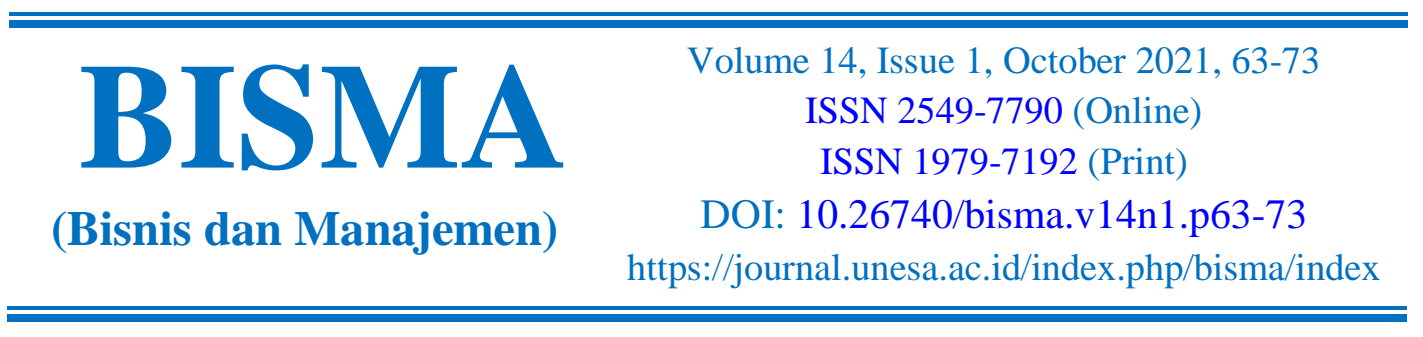

\title{
The impact of sustainable supplier selection to supplier performance in mining industry: ethical culture as moderating variable
}

\author{
Nasar Buntu Laulita* \\ Universitas Internasional Batam, Indonesia
}

\begin{abstract}
Sustainable supplier selection during tender is one of the critical factors in the supply chain management to maintain sustainable procurement in an organisation. Many factors contribute to the success of sustainable supplier selection practices, and ethical culture is one of the factors because it would influence supplier selection. This study aims to determine the effect of implementing sustainable supplier selection on supplier performance by moderating the effect of ethical culture in the mining industry. This type of research is explanatory research with hypothesis testing of 104 respondents by distributing questionnaires. The data analysis is conducted by Structural Equation Model (SEM). The research shows that the construct of sustainable supplier selection with economic, social, and environmental aspects as dimensions has a direct and significant impact on supplier performance in the mining industry. This research also shows that ethical culture has a significant moderating effect in the relationship between sustainable supplier selection and supplier performance. The managerial implication of this research is providing guideline for decision-makers to implement sustainable supplier selection by considering economic, social, and environmental aspects while maintaining an ethical culture as a part of work professionalism to maintain sustainable performance in the mining industry.
\end{abstract}

Keywords: ethical culture; mining; structural equation model; supplier performance; sustainable supplier selection.

Received: May 12, 2021; Accepted: July 1, 2021; Published: October 30, 2021

*Corresponding author

Email: nasar_bl@yahoo.com.sg

\section{To cite this document:}

Laulita, N. B. (2021). The impact of sustainable supplier selection to supplier performance in mining industry: ethical culture as moderating variable. BISMA (Bisnis dan Manajemen), 14(1), 63-73. https://doi.org/10.26740/bisma.v14n1.p63-73. 


\section{INTRODUCTION}

Kuo et al. (2015) explained that the intense global competition has made most of the production functions in the supply chain essential, including selecting suppliers in the procurement process that requires tenders (Wouters et al., 2019). Yazdani et al. (2017) also mentioned that evaluating and selecting suppliers are significant strategic decisions to reduce operational costs and increase organisational competitiveness in developing business opportunities. Several studies have explained the effect of supplier selection in the tender process. The result will be for a long-term relationship such as Lundberg \& Bergman (2017), who studied the importance of supplier selection in anticipating uncertain prices and quality differences in tenders. Abdullahi et al. (2019) also described the need for transparency in selecting supplier selection during the tender process by implementing e-tendering. In addition, Yazdani et al. (2017) said that it needs to consider environmental factors in selecting suppliers. Bai et al. (2019) emphasized the need to consider social, economic, and environmental factors in selecting suppliers for the best performance and maintain the sustainability of supplier selection.

In Indonesia, most of the supplier selection criteria during the tender process still focused on cost and quality like Bidarti et al. (2019) who studied the agriculture industry. It needs to study the sustainable supplier selection criteria during tender process in the mining industry because the impact of this industry will relate to social and environmental factors in the long term. De Felice et al. (2015) divide supplier performance into three dimensions as guidance for supplier selection, i.e., delivery quality, delivery performance and service, and communication. These dimensions are essential because those matters that relating to suppliers will affect supply chain performance about purchasing of organisations. It will have a strategic impact on reputation, good name, customer satisfaction, financial (sales) performance, and operational performance as mentioned by Jajja et al. (2016) and Mani et al. (2018). The implementation of certain system mostly is influenced by culture in the organization, especially ethical culture during supplier selection (Goebel et al., 2012). Every country and region have a different culture, so the moderating effect of ethical culture to strengthen or weaken the system such as sustainable supplier selection on the organization is very important to be studied and analysed especially in Indonesia as a country with multicultural society.

Based on the literature study and research gap, this research will aim to analyse the direct effect of sustainable supplier selection to supplier performance and the moderating the effect of ethical culture in the relationship between sustainable supplier selection and supplier performance during the tenders process in the mining industry by using SEM with the two-step approach of Ping (1995). The research is expected to contribute to determining the criteria of sustainable suppliers' selection by implementing an ethical culture to optimize the supplier performance. 
The impact of sustainable supplier selection to supplier performance in mining industry: ethical culture as moderating variable

\section{Sustainable Supplier Selection on Supplier Performance}

Several studies explained supplier performance parameters from the buyer side, such as flexibility and innovation, reduction in supply costs, problem-solving skills, innovative, creative, analytical thinking communication skills, and teamwork (Jajja et al., 2016; Landry, 2016). Some research studied the implementation of sustainable supplier selection in some areas, such as the public sector (Lundberg \& Bergman, 2017), the automobile industry (Yazdani et al., 2017), and the mining industry (Ahmad \& Mondal, 2018). Previous research verified the effect of sustainable supplier selection toward supplier performance (Lo et al., 2021; Yang \& Zang, 2017). In the mining industry, sustainable supplier selection is essential to maintain the procurement process for various spare parts in the long term. It will affect the performance of various departments such as inventory management, production planning, maintenance scheduling, financial resources, and the environment (Ortiz-Barrios et al., 2020). Hence, we hypothesize that:

H1: Sustainable supplier selection influence supplier performance directly.

\section{Moderating Effect of Ethics Culture in the Relationship of Sustainable Supplier Selection toward Supplier Performance}

Simangunsong et al. (2016) explained that ethical culture played a role in supply chain management, especially during tender supplier selection (Goebel et al., 2012). Organisation culture could influence the performance directly as mentioned by Prajogo \& McDermott (2011). However, another research such as Yesil \& Kaya (2013) mentioned that a culture did not affect the performance directly. Culture insignificantly influences the supply chain management performance (Cadden et al., 2013).

Ethics can be defined as moral principles that govern a person's behaviour or conduct. It means that ethical culture will have a moderating effect that strengthened or weaken the implementation of sustainable supplier selection because ethics and sustainability in an organisation have an operational relationship (Torelli, 2020). Research of ethical culture mainly focuses on identifying the factors that shape ethical culture and the influence on individual behaviour, attitudes, and ethical behaviour in general. There is limited study on how ethical culture impacts companies' actual decision-making and translated into economic, social, and environmental decision-making in supplier selection (Goebel et al. 2012). The moderating effect of culture in an organisation and the impact on performance have been studied by some authors such as Thumbi et al. (2020), Shi \& Veenstra (2020), and Rahman \& Ismail (2018). Furthermore, we hypothesize that:

$\mathrm{H} 2$ : Ethics culture has a moderating effect in the relationship of sustainable supplier selection and supplier performance.

By combining all hypotheses above, the research model is presented by Figure 1. 


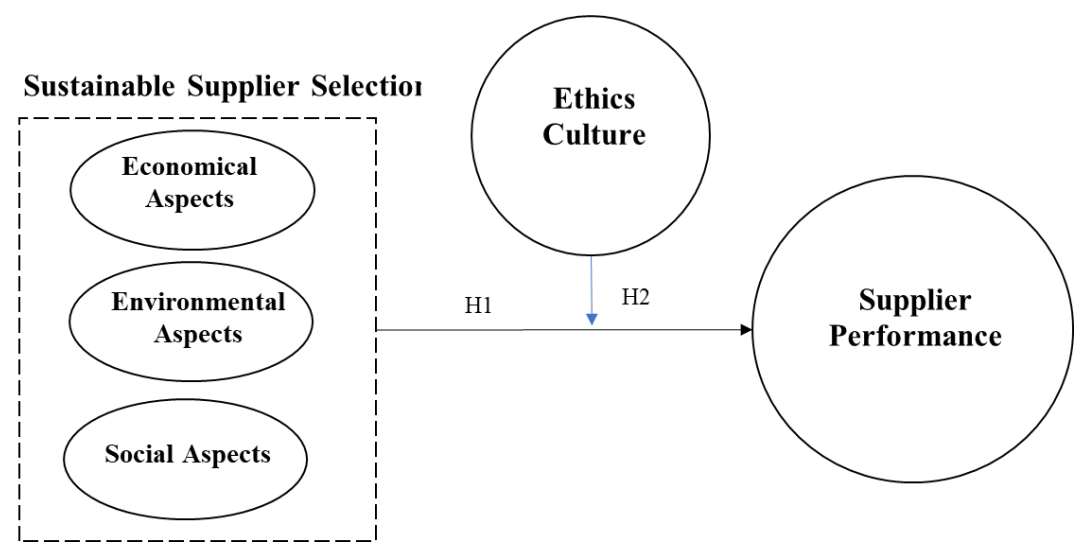

Figure 1. Research Model

\section{METHODS}

The research type was explanatory research that explained the relationship of each construct (Sekaran \& Bougie, 2016). The study population included permanent employees, contractors in procurement department and decision maker of supplier selection in PT. Berau Coal. Data were collected using an online survey method with a minimum sample size of 100 for two to five latent variables (Hair et al., 2018). The questionnaire was distributed online to all permanent employees who understood the organisational ethical culture and selected suppliers at PT. Berau Coal. From 150 questionnaires sent, 110 respondents provided the answer, and 104 samples had completed for analysis. These samples were from internal employee of PT. Berau Coal for 57 samples and 47 samples from their contractors.

The dimensions of selecting a sustainable supplier have been described by several previous studies such as Amindoust et al. (2012), Yazdani et al. (2016), Ahmadi et al. (2017) and Bai et al. (2019). This research focused on the economic, environmental, and social aspects as three dimensions of sustainable supplier selection. This research also used ten items scale to measure the construct of economic aspect from Amindoust et al. (2012), the fourteen-item scale used to measure the environmental aspect was also adopted from Amindoust et al. (2012) and Ahmadi et al. (2017) to evaluate eight statements for the social aspect. The statement indicators on ethical culture as a moderating variable with sixteen indicators from Goebel et al. (2012) and supplier performance were explained by seven statements adapted from De Felice et al. (2015). All statement items in the questionnaire were distributed to respondents using five Likert scales.

Data were analysed using SEM with a two-step approach. Ping (1995) and Baron \& Kenny (1986) mention that a single indicator shall be used for moderating variables in the SEM, where the single indicator is multiplication between indicators of exogenous construct and indicators of the moderator construct. To measure the estimation of SEM, this research used the latent variable score (LVS) of every construct. LVS is an individual score of a latent variable or constructs in the estimation of SEM, and this process is done after completing the validity and reliability test (Joreskog et al., 1999). The goodness of fit (GOF) test used in this 
Laulita, N. B.

The impact of sustainable supplier selection to supplier performance in mining industry: ethical culture as moderating variable

research are chi-square $\left(\boldsymbol{X}^{2}\right)$, the goodness of fit index (GFI), root mean square error of approximation (RMSEA), adjusted goodness of fit (AGFI), normed fit index (NFI), comparative fit index (CFI), incremental fit index (IFI), relative fit indices (RFI), Akaike's information criterion (AIC), consistent Akaike information index (CAIC), expected cross-validation index (ECVI), and parsimonious goodness of fit index (PGFI). This research uses a 95\% of confidence interval (CI), then the significance of all constructs is determined based on a t-value $\geq 1.96$ or $\leq-1.96$ (Hair et al., 2018).

\section{RESULT AND DISCUSSION Result}

The normality test results show that P-value for Skewness and Kurtosis $>0.05$ was both univariate and multivariate for all indicators and constructs, so it was continued with Confirmatory Factor Analysis (CFA) to determine the validity and reliability of the first construct indicator and the second construct of sustainable supplier selection. The reliability of the latent variables are assessed by using loading factor, average variance extracted and construct reliability values (Hair et al., 2018). The results were obtained from the validity, reliability analysis, and the CFA showed that all indicators were valid and reliable based on the value of loading factors $\geq 0.5, \mathrm{AVE} \geq 0.5$ and $\mathrm{CR} \geq 0.7$. Moreover, $\mathrm{t}$-value of the first step SEM (without interaction) is shown in figure 2.

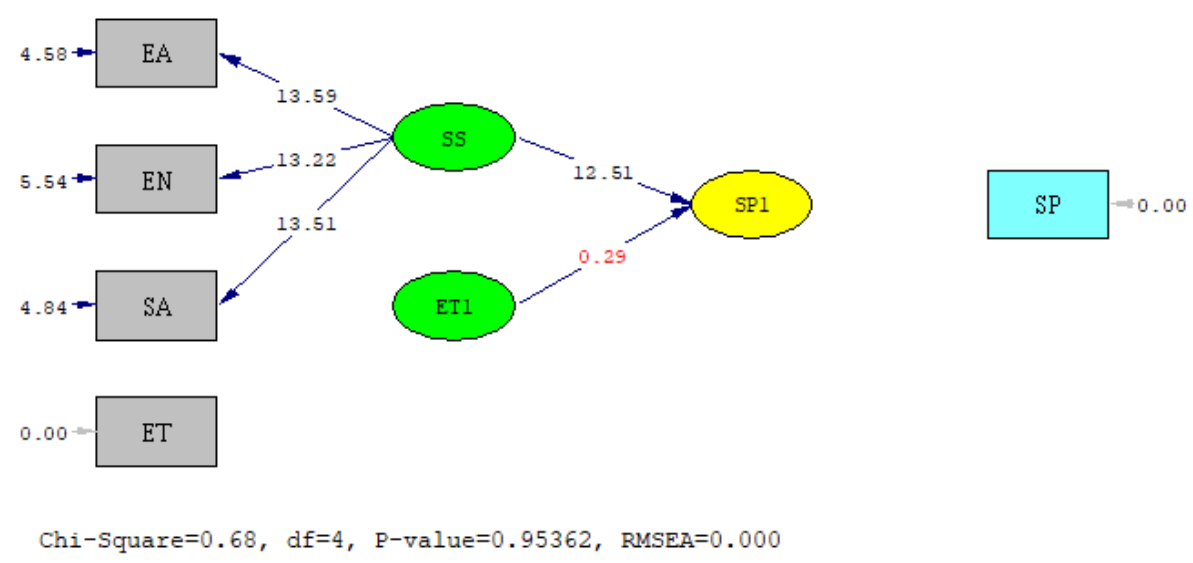

Figure 2. First step SEM (without interaction)

The output of Lisrel 8.7 as shown in figure 2 explains that the model has acceptable goodness of fit (GOF) where a ratio of chi-square value to the degree of freedom (DOF) is less than 3 with a p-value of $0.954>0.05$ and RMSEA $<0.08$ as referred to Hair et al. (2018). Another GOF criteria had also met the recommended ones such as GFI, NNFI, CFI, IFI, NFI, PGFI, ECFI, AIC and CAIC. The estimation results show that sustainable supplier selection has a direct effect on operational performance with the resulting statistical t-value $12.51>1.96$. In contrast, ethical 
culture did not significantly influence supplier performance directly, with the resulting statistical t-value of $0.29<1.96$. Furthermore, t-value of the second step SEM (with interaction) is shown in figure 3. ET and ET1 represent ethical culture which same value of latent variable score. The same thing for MOD and MOD1 which represent the moderating effect of ethical culture.

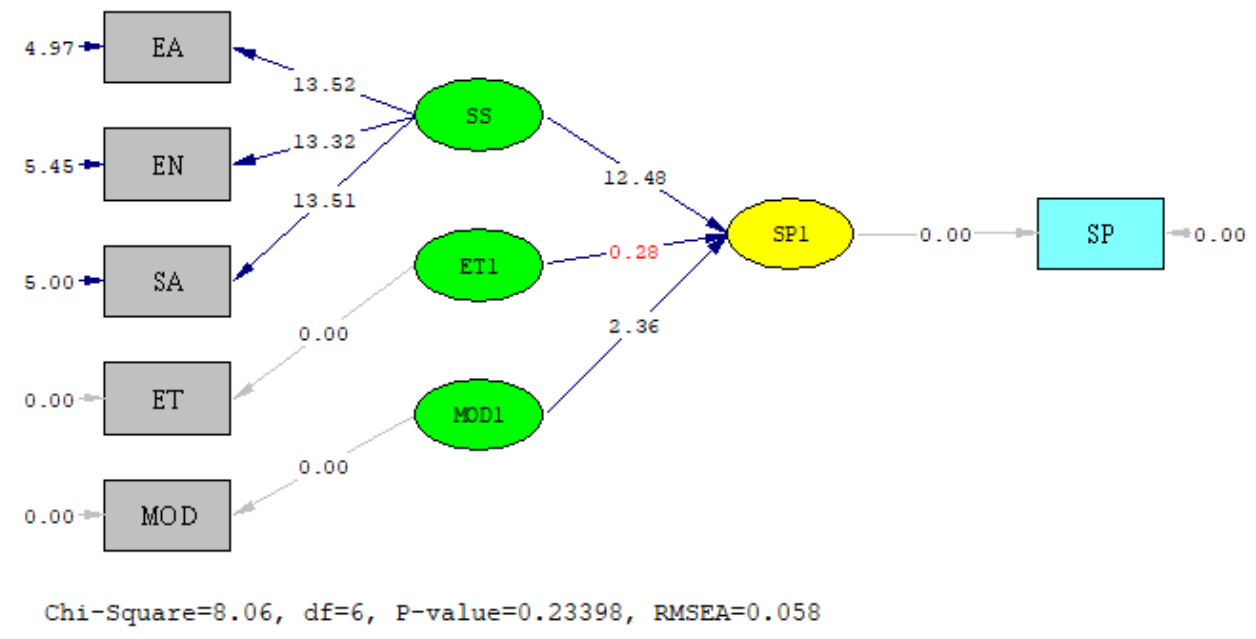

Figure 3. Second step SEM (with interaction)

Figure 3 explains that the model meets the criteria of GOF where the resulting comparison between chi-square and the DOF is less than 3 with a p-value of 0.334 $>0.05$ and RMSEA $<0.08$ by referring to Hair et al. (2018). Another goodness of fit criteria has also met the recommended requirements: GFI, NNFI, CFI, IFI, NFI, PGFI, ECFI, AIC and CAIC. The estimation result shows that sustainable supplier selection has a significant effect on operational supplier performance with the resulting t-value was $12.48>1.96$ (t-table for $\alpha=95 \%$ ). It can also be seen that ethical culture has a significant effect to moderate the relationship between sustainable supplier selection and supplier performance with the resulting statistical t-value $2.36>1.96$. Based on hypothesis testing, $\mathrm{H} 1$ and $\mathrm{H} 2$ are accepted with $\mathrm{t}$ value 12.48 and 2.36 .

\section{Discussion}

There are two main hypotheses in this research with hypothesis development on the second hypothesis about the moderating effect of ethical culture in the relationship between sustainable supplier selection and supplier performance in mining industry. Hypothesis 1 is accepted that the sustainable supplier selection has a direct effect to supplier performance which is consistent with Lo et al. (2021) and Yang \& Zang (2017). This research also supports Wouters et al. (2019) that mention the significance of sustainable supplier selection by implementing economic aspect, social aspect, and environmental aspect on performance where economic aspect will have the highest priority than social aspect and environment aspect based on t- 
The impact of sustainable supplier selection to supplier performance in mining industry: ethical culture as moderating variable

value. The results are found that sustainable supplier selection that considered economic aspect, environmental aspect and the social aspect is critical to influencing the operational performance of suppliers after tendering process in the mining industry because it can provide competitive advantages, including high quality, customer responsiveness and low costs. It means that all mining companies in Indonesia must consider these three aspects in supplier selection criteria to maintain the sustainability. In Indonesia mineral and coal mining, all activities must follow Law No.4/2009 that has a function to control all operations in mining industry that related to economic, social and environment factors. As mentioned in chapter two of this regulation that mineral and coal mining are managed based on benefits, fairness, and balance that must consider economic factor, social aspect, and environment friendly (EITI, 2009).

Hypothesis 2 is accepted that ethical culture has a moderating effect in the relationship of sustainable supplier selection and supplier performance in mining industry. This research also supported Simangunsong et al. (2016), who said that ethical culture was essential to manage supply chain uncertainty and Wesarat et al. (2017) who mentioned the importance of ethical culture in sustainable development. Ethical culture has a moderating effect of influencing the relationship between sustainable supplier selection and supplier performance because ethical culture will develop sustainability and manage supply chain uncertainty in mining industry as a response of production capacity that is based on government decision and fluctuation of mineral or coal price in the world. The mining industry in Indonesia have some rules and regulations that need to be followed in their operation include in the supplier selection process during the tender. It means that the initial culture in the company will adapt to follow the regulation to sustain in the mining industry. It is clear in the chapter XXII and XXIII of Law No.4/2009 about the sanctions and punishments if not follow the regulation. Those companies which do not follow the regulation and the law will get punishment until mining license revocation (EITI, 2009). This research is a guideline for decision-makers in an organisation, primarily during supplier selection in the mining industry to ensure the consideration of all supplier selection factors and implement ethical culture correctly in the company to maintain all performances.

\section{CONCLUSION}

Experience and studies had shown that there was no best way for evaluating and selecting a specific supplier process but that it varied from one organisation to another. This research aimed to demonstrate how an ethical culture moderates the relationship between sustainable supplier selection and operational performance during the tender process in the mining industry. In all industry, supplier selection was one of the crucial activities of an organisation. The results were found that sustainable supplier selection that considered economic aspect, environmental aspect and the social aspect is critical to influencing the operational performance of 
suppliers after tendering process in the mining industry. Ethical culture doesn't have direct effect on performance, but it has a moderating effect of influencing the relationship between sustainable supplier selection and supplier performance because ethical culture will develop sustainability and manage supply chain uncertainty. There are some limitations of this research on data sources from certain company and area only where different organisations have a different perspective also on ethical culture implementation. The effect of supplier selection needs further research by extending the study to another industry and organisation. This research used a two-step approach for analysing moderating effects, and it was one of the methods in structural equation modelling. The future research needs to compare the result from supplier point of view, using another method such as twostage least-square, maximum likelihood approach or quasi-maximum likelihood estimation and extend the research in the different environments of the mining industry.

\section{ACKNOWLEDGMENT}

The author would like to thank all employees of PT. Berau Coal was very supportive of data collection with interviews and Batam International University, which supported the funding of this research.

\section{REFERENCES}

Abdullahi, B., Ibrahim, Y. M., Ibrahim, A. D., \& Bala, K. (2019). Development of web-based e-Tendering system for Nigerian public procuring entities. International Journal of Construction Management, 1(1), 1-14. https://doi.org/10.1080/15623599.2019.1620492

Ahmad, M. T., \& Mondal, S. (2018). Dynamic supplier selection approach for mining equipment company. Journal of Modelling in Management, 14(1), 77-105. https://doi.org/10.1108/JM2-04-2018-0046.

Ahmadi, H. B., Kusi-Sarpong, S., \& Rezaei, J. (2017). Assessing the social sustainability of supply chains using Best Worst Method. Resources, Conservation \& Recycling, 126(1), 99-106. https://doi.org/10.1016/j.resconrec.2017.07.020.

Amindoust, A., Ahmed, S., Saghafinia, A., \& Bahreininejad, A. (2012). Sustainable supplier selection: A ranking model based on fuzzy inference system. Applied Soft Computing, 12(6), 1668-1677. https://doi.org/10.1016/j.asoc.2012.01.023.

Bai, C., Kusi-Sarpong, S., Ahmadi, H. B., \& Sarkis, J. (2019). Social sustainable supplier evaluation and selection: A group decision-support approach. International Journal of Production Research, 1(1), 1-22. https://doi.org/10.1080/00207543.2019.1574042. 
The impact of sustainable supplier selection to supplier performance in mining industry: ethical culture as moderating variable

Baron, R. M., \& Kenny, D. A. (1986). The Moderator-Mediator Variable Distinction in Social Psychological Research: Conceptual, Strategic, and Statistical Considerations. Journal of Personality and Social Phychology, 51(6), 1173-1182. https://doi.org/10.1037//0022-3514.51.6.1173.

Bidarti, A., Darwanto, D. H., Hartono, S., \& Jamhari. (2019). Supplier Structure and Performance Evaluation of Supplier Network Phase Rice Supply Chain Management in South Sumatra. AGRARIS: Journal of Agribusiness and Rural Develpoment Research, 5(1), 7-20. https://doi.org/10.18196/agr.5171.

Cadden, T., Marshall, D., \& Cao, G. (2013). Opposites attract: Organisational culture and supply chain performance. Supply Chain Management: An International Journal, 18(1), 86-103. https://doi.org/10.1108/13598541311293203.

De Felice, F., Deldoost, M. H., Faizollahi, M., \& Petrillo, A. (2015). Performance Measurement Model for the Supplier Selection Based on AHP. International Journal of Engineering Business Management, 7(17), 1-13. https://doi.org/10.5772/61702.

Goebel, P., Reuter, C., Pibernik, R., \& Sichtmann, C. (2012). The influence of ethical culture on supplier selection in the context of sustainable sourcing. International Journal of Production Economics, 140(1), 7-17. https://doi.org/10.1016/j.ijpe.2012.02.020.

Hair, J. F., Babin, B. J., Anderson, R. E., \& Black, W. C. (2019). Multivariate Data Analysis (8th ed.). Boston: Cengage.

Jajja, M. S. S., Kannan, V. R., Brah, S. A., \& Hassan, S. Z. (2016). Supply chain strategy and the role of suppliers: Evidence from the Indian sub-continent. Benchmarking: An International Journal, 23(7), 1658-1676. https://doi.org/10.1108/BIJ-06-2014-0058.

Joreskog, K. G., Sorbom, D., Du Toit, S., \& Du Toit, M. (1999). LISREL 8: New Statistical Features. Lincolnwood, IL: Scientific Software International.

Kuo, R. J., Pai, C. M., Lin, R. H., \& Chu, H. C. (2015). The integration of association rule mining and artificial immune network for supplier selection and order quantity allocation. Applied Mathematics and Computation, 250(2015), 958-972. https://doi.org/10.1016/j.amc.2014.11.015.

Landry, D. J. (2016). The case of certification of the innovation professional. International Journal of Innovation Science, 8(1), 27-38. https://doi.org/10.1108/IJIS-03-2016-002.

Lo, H., Liaw, C., Gul, M., \& Lin, K. (2021). Sustainable supplier evaluation and transportation planning in multi-level supply chain networks using multiattribute- and multi-objective decision making. Computers and Industrial Engineering, 162 https://doi.org/10.1016/j.cie.2021.107756. 
Lundberg, S., \& Bergman, M. A. (2017). Tendering design when price and quality is uncertain. International Journal of Public Sector Management, 30(4), 310 327. https://doi.org/10.1108/IJPSM-04-2016-0063.

Mani, V., Gunasekaran, A., \& Delgado, C. (2018). Enhancing supply chain performance through supplier social sustainability: An emerging economy perspective. International Journal of Production Economics, 195(1), 259272. https://doi.org/10.1016/j.ijpe.2017.10.025.

Ortiz-Barrios, M., Cabarcas-Reyes, J., Ishizaka, A., Barbati, M., Jaramillo-Rueda, N., \& de Jesús Carrascal-Zambrano, G. (2020). A hybrid fuzzy multi-criteria decision making model for selecting a sustainable supplier of forklift flters: A case study from the mining industry. Annals of Operations Research, 1(1), 1-39. https://doi.org/10.1007/s10479-020-03737-y.

Ping, R. A. (1995). A parsimonious estimating technique for interaction and quadratic latent variables. Journal of Marketing Research, 32(3), 336-347. https://doi.org/10.1177\%2F002224379503200308.

Prajogo, D., \& McDermott, C. (2011). The relationship between multidimensional organizational culture and performance. International Journal Operational Production Management, 31(7), 712-735. https://doi.org/10.1108/01443571111144823.

Rahman, I. M. A., \& Ismail, K. N. I. K. (2018). The Moderating Effect of Culture on the Relationship between Women Directors and CSR Disclosure in Malaysia. Asian Journal of Accounting and Governance, 9(1), 133-141. https://dx.doi.org/10.17576/AJAG-2018-09-12.

Sekaran, U., \& Bougie, R. (2016). Research methods for business: A skill-building approach (7th ed.). Chichester, West Sussex, UK: John Wiley \& Sons.

Shi, W., \& Veenstra, K. (2020). The Moderating Efect of Cultural Values on the Relationship Between Corporate Social Performance and Firm Performance. Journal of Business Ethics, 1(1), 1-19. https://doi.org/10.1007/s10551-02004555-9.

Simangunsong, E., Hendry, L. C., \& Stevenson, M. (2016). Managing supply chain uncertainty with emerging ethical issues. International Journal of Operations \& Production Management, 36(10), 1272-1307. https://doi.org/10.1108/IJOPM-12-2014-0599.

Thumbi, N. P., Hannah, B., \& Rosemarie, W. (2020). Moderating Effect of Organizational Culture on the Relationship between Organizational Learning and Employees' Performance in Classified Hospitality Firms in Kenya. International Journal of Business and Management, 15(12), 51-61. http://dx.doi.org/10.5539/ijbm.v15n12p51. 
The impact of sustainable supplier selection to supplier performance in mining industry: ethical culture as moderating variable

Torelli, R. (2020). Sustainability, responsibility and ethics: Different concepts for a single path. Social Responsibility Journal, 1(1), 1-21. https://doi.org/10.1108/SRJ-03-2020-0081.

UNDANG-UNDANG REPUBLIK INDONESIA NOMOR 4 TAHUN 2009 TENTANG PERTAMBANGAN DAN BATU BARA (2009. Kementerian Energi dan Sumber Daya Mineral. Retrieved from https://eiti.ekon.go.id/v2/wp-content/uploads/2017/07/UU-4-TAHUN2009.pdf.

Wesarat, P., Sharif, M. Y., \& Abdul Majid, A. H. (2017). Role of Organizational Ethics in Sustainable Development: A Conceptual Framework. International Journal Sustainable Future for Human Security, 5(1), 67-76. https://doi.org/10.24910/jsustain/5.1/6776.

Wouters, O. J., Sandberg, D. M., Pillay, A., \& Kanavos, P. G. (2019). The impact of pharmaceutical tendering on prices and market concentration in South Africa over a 14-year period. Social Science \& Medicine, 220(1), 362-370. https://doi.org/10.1016/j.socscimed.2018.11.029.

Yang, F., \& Zhang, X. (2017). The impact of sustainable supplier management practices on buyer-supplier performance: An empirical study in china. Review of International Business and Strategy, 27(1), 112-132. https://doi.org/10.1108/RIBS-08-2016-0043.

Yazdani, M., Chatterjee, P., Zavadskas, E. K., \& Zolfani, S. H. (2017). Integrated QFD-MCDM framework for green supplier selection. Journal of Cleaner Production, 142(4),

3728-3740. https://doi.org/10.1016/j.jclepro.2016.10.095.

Yesil, S., \& Kaya, A. (2013). The effect of organizational culture on firm financial performance: Evidence from a developing country. Procedia - Social and Behavioral Sciences, 81(1), 428-437. https://doi.org/10. 1016/j.sbspro.2013.06.455. 